\title{
EXTENSIVE PROTEIN SIMILARITY OF THE HYBRIDIZING CHICKADEES PARUS ATRICAPILLUS AND P. CAROLINENSIS
}

\author{
Michael J. BRAUN ${ }^{1,3}$ AND MARK B. ROBBINS ${ }^{2,4}$ \\ 'Department of Biochemistry, Louisiana State University Medical Center, 1901 Perdido Street, \\ New Orleans, Louisiana 70112 USA, and \\ ${ }^{2}$ Museum of Zoology, Louisiana State University, Baton Rouge, Louisiana 70893 USA
}

\begin{abstract}
Starch gel electrophoresis of proteins was used to assess genetic differentiation and introgression across a contact zone between Parus atricapillus and P. carolinensis. Little or no differentiation was found at 35 presumed genetic loci, even between distantly allopatric population samples. Nei's (1978) genetic distance $(D)$ was $\leq 0.001$ for all comparisons. In contrast, Parus gambeli, another chickadee known to hybridize with atricapillus, was well differentiated at 3 loci $(D \approx 0.065)$. While the data suggest that atricapillus and carolinensis are closely related, they do not allow conclusions on the extent of introgression across the contact zone. The implications of these data are discussed in the light of the emerging pattern of isozyme variation in birds. Received 26 August 1985, accepted 28 March 1986.
\end{abstract}

THE evolutionary implications of hybridization in a contact zone depend on the extent to which gene flow is promoted by that hybridization. If the rate of gene flow is substantial, the hybridizing organisms form an evolutionary unit in the sense that most of the genetic variation available to one form is also available to the other. If gene flow is seriously impaired in the contact zone, then the hybridizing forms may be more or less genetically independent of one another. For most contact zones, the rate of gene flow can be inferred from the extent of introgression of parental characteristics across the zone. In the case of the Black-capped and Carolina chickadees (Parus atricapillus and $P$. carolinensis), however, achieving an accurate assessment of gene flow across their contact zone has been, and continues to be, difficult.

Previous studies of hybridization between these chickadees have established that interbreeding is common in many areas of contact (Brewer 1963, Rising 1968, Johnston 1971, Robbins et al. 1986). However, the amount of genetic introgression resulting from this interbreeding is unknown for two reasons. First, the two parental forms are extremely similar in all

\footnotetext{
${ }^{3}$ Present address: Program Resources, Inc., NCIFrederick Cancer Research Facility, Building 560, P.O. Box B, Frederick, Maryland 21701 USA.

${ }^{4}$ Present address: Academy of Natural Sciences, 19th Street and the Parkway, Phildelphia, Pennsylvania 19103 USA.
}

morphological and ecological characteristics. Thus, an atricapillus population introgressed with carolinensis characters would be hardly distinguishable from a pure atricapillus population, and vice versa. Furthermore, because the contact zone parallels an obvious ecotone in some areas, the possibility remains that selection gradients have produced the observed morphological differences (Robbins et al. 1986). Second, although the songs of the two forms are strikingly different, the value of vocal characters as markers of gene flow is questionable because learning may be involved in song ontogeny (Ficken 1981, Ficken pers. comm.), or dispersing individuals may adopt the song type of the local population in which they breed (Payne 1981).

These difficulties with traditional characters led to interest in other markers that could be used to trace gene flow across the contact zone. Isozymic traits determined by protein electrophoresis are attractive prospects as genetic markers because they provide discontinuous characters that generally are inherited in a simple Mendelian fashion. If a large portion of protein variation is selectively neutral, as has been suggested repeatedly (e.g. King and Jukes 1969, Kimura 1983, Barrowclough et al. 1985), then loci that are differentiated across contact zones may provide silent markers through which demographic processes can be observed. A number of surveys of avian contact zones have employed this technique (Corbin et al. 
1979, Barrowclough 1980, Corbin 1981, Johnson and Zink 1983, Braun et al. 1984). Such studies yield valuable information on the genetics of wild bird populations in general, as well as on the evolutionary implications of contact zones (Barrowclough 1983).

\section{MATERIALS AND MethodS}

Sixty-nine specimens were analyzed electrophoretically, including 20 atricapillus from northern Missouri (Nodaway Co.), 20 carolinensis from Louisiana (St. Charles Parish), 14 birds from the contact zone in west-central Missouri (Bates and St. Clair cos.), and 15 Parus gambeli from California (San Bernardino Co.). Of the 14 contact zone birds, 13 were used previously in a multivariate analysis of morphological intermediacy in the contact zone (Robbins et al. 1986). Although these 13 birds cannot be identified safely as parentals, hybrids, etc. in terms of their morphological discriminant scores, they were representative of the entire contact zone sample, because the distribution of their discriminant scores did not differ significantly from the distribution of the entire sample (Kolmogorov-Smirnov test). All birds were collected with shotguns and frozen immediately on dry ice in the field. Later, the birds were thawed and heart, liver, kidney, and pectoral muscle collected. Tissue samples were stored at $-60^{\circ} \mathrm{C}$ until use. Study skins and frozen tissue samples are preserved in the collections of the Louisiana State University Museum of Zoology.

Tissue samples were homogenized with 1-2 volumes of distilled water and clarified by centrifugation. Fifteen to $20 \mu \mathrm{l}$ of the supernatant were loaded onto $10 \%$ starch gels and vertical electrophoresis carried out at $6 \mathrm{~V} / \mathrm{cm}$ for $12-24 \mathrm{~h}$. Specific staining techniques similar to those described by Harris and Hopkinson (1976) and Brewer (1970) were used to identify 35 presumed genetic loci. The loci assayed and the electrophoretic conditions used are summarized in the Appendix. When more than one locus with a particular enzymatic activity was scored, the loci were numbered beginning with the most anodal. Multiple alleles at a locus were designated alphabetically, beginning with the most anodal. Each bird was assigned a presumed genotype based on the pattern of bands in its electrophoretic phenotype.

The BIOSYS-1 computer program (Swofford and Selander 1981) was used to calculate indices of genetic variability and the genetic distances of Nei (1978) and Rogers (1972). The conformance of each population to Hardy-Weinberg expectations was assessed using a Chi-square test and an exact probability test (Elston and Forthofer 1977). To preserve sample sizes for tests of loci with more than two alleles, genotypes were pooled into three classes: homozygotes for the most common allele, heterozygotes for the most common allele and another allele, and all other genotypes.

$F$-statistics were calculated by the method of Wright (1978) using BIOSYS-1. These statistics provide a means for analyzing population breeding structure in terms of correlations between uniting gametes. Barrowclough (1983) discussed the use of these statistics in analyzing avian populations. $F_{\text {is }}$ and $F_{\text {it }}$ are fixation indices of the individual with respect to its subpopulation and the total sample, respectively. $F_{\text {st }}$ provides a measure of the differentiation of the subpopulations in terms of their progress toward complete fixation for alternate alleles. $F_{\mathrm{st}}$ has advantages over genetic distance in that it can be used to compare more than two populations simultaneously. It should be borne in mind, however, that $F_{\mathrm{st}}$ measures progress toward fixation, not absolute differentiation, and generally has smaller values when heterozygosity is high (Wright 1978).

\section{RESULTS}

Variation within populations.-Of 35 loci surveyed, 15 were polymorphic in one or more populations (Appendix). Eleven loci were only slightly polymorphic, however, having a single allele at a frequency greater than 0.05 . Mean heterozygosities and percentages of polymorphic loci (Table 1) indicated that the variability of each population was within the range of values previously observed in passerine birds (Barrowclough 1980) and vertebrates in general (Nevo 1978). Values of $F_{\text {is }}$ for polymorphic loci (Table 2) were generally small, indicating little deviation from panmixia within local populations. A possible exception involved the dipeptidase-1 locus (see below). The mean of $F_{\text {is }}$ over all polymorphic loci was not significantly different from zero ( $t$-test).

Tests for conformance to Hardy-Weinberg equilibrium revealed only one case of heterozygote deficiency that approached statistical significance: the dipeptidase- 1 locus in the contact zone population $(P=0.031$, Chi-square test; $P=0.064$, exact probability test). The biological significance of this deviation is questionable, however, because it results from an observation of two heterozygous individuals when only 4.7 heterozygotes were expected. Furthermore, because even allopatric atricapillus and carolinensis population samples were virtually identical in allelic frequency at this locus (Appendix), the relationship of any possible heterozygote deficiency to interbreeding between the two forms is unclear. 
TABLE 1. Measures of genetic variability at 35 loci in 4 chickadee populations.

\begin{tabular}{cccc}
\hline \hline & $\begin{array}{c}\text { Percent- } \\
\text { age of } \\
\text { poly- }\end{array}$ & \multicolumn{2}{c}{ Mean heterozygosity \pm SE } \\
\cline { 3 - 4 } $\begin{array}{c}\text { Popula- } \\
\text { morphic } \\
\text { tion }\end{array}$ & loci $^{\mathrm{a}}$ & Direct count & $\begin{array}{c}\text { Hardy-Weinberg } \\
\text { expected } \\
\text { (Nei 1978) }\end{array}$ \\
\hline $\begin{array}{c}\text { carolin- } \\
\text { ensis } \\
\text { atricapil- } \\
\text { lus }\end{array}$ & 31.4 & $0.042 \pm 0.015$ & $0.043 \pm 0.015$ \\
$\begin{array}{c}\text { Contact } \\
\text { zone }\end{array}$ & 22.9 & $0.046 \pm 0.021$ & $0.044 \pm 0.020$ \\
gambeli & 15.2 & $0.020 \pm 0.009$ & $0.020 \pm 0.009$ \\
\hline
\end{tabular}

a $A$ locus was considered polymorphic if no allele exceeded 0.99 in frequency.

b Values for gambeli are over 33 loci.

Variation among populations. - The northern Missouri atricapillus sample and the Louisiana carolinensis sample were extremely similar in allelic frequencies at the 35 loci studied (Appendix). Only one allele occurred in one sample at an appreciable frequency and not in the other. This was the proline dipeptidase-2a allele, which occurred in atricapillus at a frequency of 0.125 but was not found in the carolinensis sample. An allele with such a low frequency is not promising for use as a genetic marker, however, because of the potential sampling error involved. For example, if carolinensis populations actually had the allele at the same frequency as the atricapillus sample, it would require a sample of about 50 individuals to ensure with $95 \%$ probability that the allele would be found (Gregorius 1980). With a sample size of 20 for each population, it is far from certain that the two populations actually differ in the frequency of proline dipeptidase-2a.

For the multilocus comparisons, the genetic distances between atricapillus, carolinensis, and contact zone samples were very small (Table 3 ). These values indicate a level of divergence more typical of local avian populations rather than levels generally achieved by separate avian species (Barrowclough 1980). The same conclusion may be drawn from the summary of F-statistics (Table 2). All $F_{\text {st }}$ values were small, and the mean of $F_{\text {st }}$ over all polymorphic loci $\left(\bar{F}_{\text {st }}\right)$ is practically identical to the mean of $\bar{F}_{\text {st }}(0.022)$ from a number of previous studies of conspecific bird populations (Barrowclough 1983).

Given the high degree of molecular similarity of the atricapillus and carolinensis samples, it
TABLE 2. F-statistics (Wright 1978) for 15 variable loci in 3 chickadee populations ( $P$. gambeli not included). Values shown are the weighted averages across alleles at a locus. See the Appendix for locus abbreviations.

\begin{tabular}{lrrr}
\hline \hline Locus & \multicolumn{1}{c}{$F_{\text {is }}$} & \multicolumn{1}{c}{$F_{\text {it }}$} & \multicolumn{1}{c}{$F_{\text {st }}$} \\
\hline TRI-1 & -0.037 & -0.012 & 0.024 \\
PRO-1 & -0.076 & -0.028 & 0.045 \\
DIP-1 & 0.165 & 0.167 & 0.002 \\
PRO-2 & 0.051 & 0.083 & 0.034 \\
TRI-2 & -0.026 & -0.008 & 0.017 \\
DIP-2 & -0.053 & -0.017 & 0.034 \\
EST-1 & -0.043 & -0.020 & 0.023 \\
ICD-2 & -0.056 & -0.018 & 0.036 \\
GPD-2 & -0.037 & -0.012 & 0.024 \\
PGM & -0.026 & -0.013 & 0.013 \\
AAT-1 & -0.032 & -0.016 & 0.016 \\
AAT-2 & -0.026 & -0.008 & 0.017 \\
MPI & -0.076 & -0.051 & 0.024 \\
CK-M & -0.026 & -0.008 & 0.017 \\
IDH & -0.034 & -0.011 & 0.022 \\
$\bar{x} \pm$ SD & -0.022 & 0.002 & 0.023 \\
& \pm 0.059 & \pm 0.054 & \pm 0.011 \\
\hline
\end{tabular}

was of interest to determine if other species of chickadees could be distinguished on the basis of protein patterns. We compared a sample of 15 Parus gambeli with the eastern chickadee samples. The $P$. gambeli were fixed for an alternate allele at the alanine aminotransferase- 2 locus, and showed large frequency differences at both the proline dipeptidase- 1 and the dipeptidase-1 loci (Appendix). These differences were reflected in the overall genetic distance measures (Table 3). Clearly, molecular differentiation was detectable in gambeli, a species closely related to the atricapillus-carolinensis complex (see below).

\section{DisCUSSION}

The extensive molecular similarity of $P$. atricapillus and $P$. carolinensis samples in this study was striking. The samples represent populations that are differentiated morphologically and vocally and are currently considered to belong to distinct species. The populations sampled are separated by $1,200 \mathrm{~km}$. Also, the narrow contact zone presumably could restrict gene flow. Yet, these samples are essentially indistinguishable at the protein loci examined. We considered several possible explanations for this observation.

First, it seemed possible that the lack of pro- 
TABLE 3. Genetic distances over 35 loci between 4 chickadee populations. Below diagonal: Nei's (1978) distance; above diagonal: Rogers's (1972) distance.

\begin{tabular}{llcccc}
\hline \hline & Population & 1 & 2 & 3 & 4 \\
\hline 1 & carolinensis & - & 0.021 & 0.023 & 0.089 \\
2 & atricapillus & 0.001 & - & 0.011 & 0.080 \\
3 & Contact zone & 0.001 & 0.000 & - & 0.085 \\
4 & gambeli $^{\text {sam }}$ & 0.072 & 0.063 & 0.066 & - \\
\hline
\end{tabular}

a Values for gambeli are over 33 loci.

tein differences reflected something unusual about the cellular biology or genetics of chickadees that precluded detectable molecular differentiation. This possibility was considered by Barrowclough and Corbin (1978) and Aquadro and Avise (1982) in exploring small genetic distances between other bird species. Although it is unclear what mechanism could bring about such an effect, it probably would be related to an alleged slowdown in avian molecular evolution (Prager et al. 1974). We reasoned that if electrophoretically detectable molecular differentiation was, in fact, forbidden in chickadees, other chickadee species also would be indistinguishable by electrophoresis. Therefore, we compared eastern chickadees with P. gambeli, a close relative of the atricapillus-carolinensis complex. Although widely sympatric in the western United States, gambeli and atricapillus hybridize along the Rio Grande in New Mexico (W. Howe pers. comm.). Compared with population samples from the eastern complex, gambeli was strongly differentiated at several loci. Thus, there appears to be no consistent bias against electrophoretically detectable protein differentiation between chickadee species. We note also that at least some putatively conspecific Parus populations are known to have genetic divergence detectable by electrophoresis. Braun et al. (1984) found significant molecular differentiation between the black-crested and gray-crested forms of the Tufted Titmouse (Parus bicolor). These forms hybridize locally in a narrow contact zone in Texas (Dixon 1955). These studies of other Parus populations imply that there is nothing unusual about the genus that would preclude electrophoretic detection of differentiation between atricapillus and carolinensis.

Next, it was pertinent to determine whether our techniques uncovered all the differentiation actually present at the loci surveyed. In- creased electrophoretic variation can be detected by systematically varying the experimental conditions (e.g. Coyne et al. 1979). The number of hidden alleles, however, may amount to only $10-20 \%$ of the final total of alleles (Aquadro and Avise 1982). A number of factors tended to ameliorate this shortcoming in our data; for example, a large number of buffer vs. locus combinations were examined in optimizing the clarity of banding patterns. Also, it is evident from the data of Aquadro and Avise (1982) that a significant portion of "hidden" variation may be detected by simply running gels longer. We routinely performed overnight runs. Finally, no electrophoretic survey can be truly exhaustive. There are certain to be many alleles that are undetectable by electrophoresis (Coyne et al. 1979), and staining techniques exist for only a small fraction of all structural genes. Considering these limitations, it appeared more reasonable to survey many loci for differentiation rather than to investigate intensively all the variation at a few.

The simplest conclusion is that these two forms have undergone very little divergence, at least at the loci analyzed. The Nei genetic distance $(D=0.001)$ between atricapillus and carolinensis is among the lowest ever reported for putative biological species. Few nonavian species comparisons approach this level of similarity. For example, in a survey of 616 pairwise comparisons of nonavian congeners, Avise et al. (1975) found only a few with $D<0.05$. However, the emerging pattern of isozyme variation in birds entails much lower genetic distances than are generally found in nonavian groups (reviewed by Avise and Aquadro 1982). For instance, Barrowclough (1980) reported a mean $D$ of 0.044 for 72 comparisons among bird congeners. Among parulid warblers, Avise et al. (1980) found a mean $D$ of 0.056 among congeneric species ( 74 comparisons). In 21 of these comparisons (28\%), $D$ was of the same order of magnitude as that between atricapillus and carolinensis in the present case $(D<0.01)$. All comparisons were among forms for which there was no doubt about their species status. As Avise et al. (1980) correctly intimated, the confidence interval of such small genetic distances is relatively large, given the sample sizes used. Nevertheless, these examples and others (Yang and Patton 1981, Johnson and Zink 1983) suggest that Nei distances less than 0.01 between 
biological species are not unusual in birds. The fact that low genetic distances seem to characterize birds has evoked considerable discussion (Sibley and Ahlquist 1982, Avise 1983) and may be related to the large effective population size and high vagility of most avian species (Barrowclough 1983). In any case, extreme protein similarity cannot by itself be taken as strong evidence for conspecificity of bird populations.

Data compiled in this and a related study (Robbins et al. 1986) suggest that Black-capped and Carolina chickadees are extremely similar genetically and interbreed freely in at least one zone of contact (southwestern Missouri). The most likely reproductive isolating mechanism, song, breaks down completely in this zone. This evidence might be sufficient grounds for considering two forms conspecific in most cases; yet the evidence falls short of conclusively demonstrating introgression between their gene pools. Paradoxically, this occurs because no known differences between these chickadees are sufficient to be useful for measuring introgression across the contact zone. In this regard, it is ironic that Black-crested and Tufted titmice, two Parus forms much more differentiated at the morphological and molecular levels than are atricapillus and carolinensis (Dixon 1955, Braun et al. 1984), are now considered subspecies (A.O.U. 1983) because their differences allowed assessment of genetic interaction between them.

We probably would not hesitate to treat Blackcapped and Carolina chickadees as a single species were it not for repeated reports of narrow gaps in their breeding ranges (Tanner 1952; Brewer 1963; Merritt 1978, 1981) that have been suggested to be induced competitively (Tanner 1952) or to act as a reproductive isolating mechanism (Brewer 1963). Robbins et al. (1986) discussed possible alternative explanations for the apparent allopatry observed by Brewer (1963) and Merritt $(1978,1981)$ in Indiana and Illinois. The elevational gap in the Great Smoky Mountains might indicate a reluctance of atricapillus and carolinensis populations in this area to interbreed despite the presence of apparently suitable habitat (Tanner 1952). The two forms hybridize in several localities in the Appalachian region (Tanner 1952, Johnston 1971), suggesting that their separation in the Great Smokies is a local phenomenon that must be studied carefully before universal significance can be attached to it. Kendeigh and Fawver (1981) demonstrated that chickadees are segregated by habitat in this area. Perhaps chickadee populations in the Great Smokies have innate habitat preferences and remain differentiated in that area. Different habitat preferences might have developed during postulated periods of Pleistocene isolation (Brewer 1963). The Great Smokies support nearly virgin forests of exceptionally high plant species diversity (Whittaker 1956), and have a greater area at high elevation than much of the rest of Appalachia (Tanner 1952). These factors help explain how habitat segregation could be more effective in the Great Smokies than in other areas of Appalachia. The idea that innate habitat preferences result in elevational separation and maintain differentiation in these populations is at least as attractive as Tanner's (1952) hypothesis that elevational separation is competitively induced, because in most areas chickadee populations interbreed extensively at the range interface (Robbins et al. 1986). Although one can understand how one species might competitively replace another, it is hard to conceive how competition could induce a gap where a significant amount of habitat is not used by either species, as occurs in the present case.

Elevational separation of this sort is not unknown for populations considered to represent subspecies of a single species. The Red-shafted and Gilded races of the Northern Flicker ( $\mathrm{Co}$ laptes auratus) hybridize in several Arizona localities, but in other areas are separated elevationally (Phillips et al. 1964). The distribution of the Alpine and Willow races of the Willow Tit (Parus m. montanus and P. m. salicarius) in the Swiss Alps provides a striking parallel to the distribution of chickadees in Appalachia (Thönen 1962). The two European forms have vocal and morphological differences at least as great as those of atricapillus and carolinensis. There are three known zones of hybridization for the European forms, but there are also areas where no hybrids have been found even though only the Willow song type occurs on one side of a valley and only the Alpine song type on the other. The similarity extends to the behavior of individual contact zone birds, which often sing both song types. The situation in the montanus-salicarius complex is nearly identical to the atricapillus-carolinensis situation, yet the vaga- 
ries of taxonomy have not yet resulted in equal categorical rank in both cases.

Although additional information may be necessary before a decision about the specific status of carolinensis and atricapillus can be made, they have passed one commonly applied test of conspecificity. Whenever the two forms breed syntopically, they hybridize readily and probably at random (Robbins et al. 1986). Thus, they do not qualify as a case where local breakdown of reproductive isolating mechanisms has caused hybridization between species that are clearly distinct in other areas, such as the towhees Pipilo ocai and P. erythrophthalmus (Sibley and Sibley 1964, Braun 1983), the paradise flycatchers Terpsiphone rufiventer, T. rufocinerea, and T. viridis (Chapin 1948), or the sparrows Passer domesticus and $P$. hispaniolensis (Meise 1936). Fortunately, in the chickadee case, further research probably will yield information useful in understanding the evolution and dynamics of their contact zone and in making an objective decision on their species status.

\section{ACKNOWLEDGMENTS}

H. C. Dessauer provided us with indispensable guidance and excellent laboratory facilities. $\mathrm{H}$. C. Dessauer, E. Tobey, N. K. Johnson, and R. H. Matson critically read the manuscript. For aid in securing tissue samples, we thank S. Cardiff, H. D. Bradshaw, Jr., L. D. Densmore III, and N. Lanson, Jr. K. Cambre helped with computer runs. We thank W. Howe for permission to cite his unpublished data. Financial support for the laboratory work was provided by the Alexander Wetmore Fund of the American Ornithologists' Union.

\section{LiteRATURE Cited}

AMERICAN ORNITHOLOGISTS' UNION. 1983. Check-list of North American birds, 6th ed. Washington, D.C., Amer. Ornithol. Union.

Aquadro, C. F., \& J. C. Avise. 1982. Evolutionary genetics of birds, VI. A reexamination of protein divergence using varied electrophoretic conditions. Evolution 36: 1003-1019.

AvisE, J. C. 1983. Commentary on "Biochemical studies of microevolutionary processes." Pp. 262270 in Perspectives in ornithology (A. H. Brush and G. A. Clark, Jr., Eds.). New York, Cambridge Univ. Press.

$\longrightarrow$ \& C. F. Aquadro. 1982. A comparative summary of genetic distances in the vertebrates: patterns and correlations. Evol. Biol. 15: 151-185.

- J. C. Patton, \& C. F. Aquadro. 1980. Evolutionary genetics of birds. Comparative molec- ular evolution in New World warblers and rodents. J. Heredity 712: 303-310.

— J. J. SmITh, \& F. J. Ayala. 1975. Adaptive differentiation with little genic change between two native California minnows. Evolution 29: 411-426.

BARROWCLOUGH, G. F. 1980. Genetic and phenotypic differentiation in a wood warbler (genus Dendroica) hybrid zone. Auk 97: 656-668.

- 1983. Biochemical studies of microevolutionary processes. Pp. 223-261 in Perspectives in ornithology (A. H. Brush and G. A. Clark, Jr., Eds.). New York, Cambridge Univ. Press.

, \& K. W. Corbin. 1978. Genetic variation and differentiation in the Parulidae. Auk 95: 691-702.

— N. K. JoHNSON, \& R. M. ZINK. 1985. On the nature of genic variation in birds. Pp. 135-154 in Current ornithology, vol. 2 (R. F. Johnston, Ed.). New York, Plenum Publ. Co.

Braun, D. D., G. B. KitTo, \& M. J. Braun. 1984. Molecular population genetics of Tufted and Blackcrested forms of Parus bicolor. Auk 102: 170-173.

BRAUN, M. J. 1983. Molecular vs. morphological and behavioral differentiation across contact zones between closely related avian species. Unpublished Ph.D. dissertation, New Orleans, Louisiana State Univ. Medical Ctr.

BREWER, G. J. 1970. An introduction to isozyme techniques. New York, Academic Press.

BREWER, R. 1963. Ecological and reproductive relationships of Black-capped and Carolina chickadees. Auk 80: 9-47.

ChAPIN, J. P. 1948. Variation and hybridization among the paradise flycatchers of Africa. Evolution 2: 111-126.

Corbin, K. W. 1981. Genic heterozygosity in the White-crowned Sparrow: a potential index to boundaries between subspecies. Auk 98: 669-680.

- C. G. Sibley, \& A. Ferguson. 1979. Genic changes associated with the establishment of sympatry in orioles of the genus Icterus. Evolution 33: 624-633.

Coyne, J. A., W. F. EANES, J. A. M. RamshaW, \& R. K. KOEHN. 1979. Electrophoretic heterogeneity of alpha-glycerophosphate dehydrogenase among many species of Drosophila. Syst. Zool. 28: 164175.

Dixon, K. L. 1955. An ecological analysis of the interbreeding of Crested Titmice in Texas. Univ. California Publ. Zool. 54: 125-206.

Elston, R. C., \& R. FORTHOFER. 1977. Testing for Hardy-Weinberg equilibrium in small samples. Biometrics 33: 6536-6542.

FICKEN, M. S. 1981. What is the song of the Blackcapped Chickadee? Condor 83: 384-386.

GregorIUS, H. R. 1980. The probability of losing an allele when diploid genotypes are sampled. Biometrics 36: 643-652. 
HARRIS, H., \& D. A. HoPKINSON. 1976. Handbook of enzyme electrophoresis in human genetics. Amsterdam, North-Holland Publ. Co.

JoHnson, N. K., \& R. M. ZINK. 1983. Speciation in sapsuckers (Sphyrapicus): I. Genetic differentiation. Auk 100: 871-884.

JOHNSTON, D. W. 1971. Ecological aspects of hybridizing chickadees (Parus) in Virginia. Amer. Midl. Natur. 85: 124-134.

KendeIGH, S. C., \& B. J. FAwVER. 1981. Breeding bird populations in the Great Smoky Mountains, Tennessee and North Carolina. Wilson Bull. 93: 218242.

KimURA, M. 1983. The neutral theory of molecular evolution. Pp. 208-233 in Evolution of genes and proteins (M. Nei and R. K. Koehn, Eds.). Sunderland, Massachusetts, Sinauer Assoc.

KING, J. L., \& T. H. JUKES. 1969. Non-Darwinian evolution: random fixation of selectively neutral alleles. Science 164: 786-798.

MeIse, W. 1936. Zur Systematik und Verbreitungsgeschichte der Haus und Weidensperlinge, Passer domesticus (L.) und hispaniolensis (T.). J. Ornithol. 84: 631-672.

MerRITT, P. G. 1978. Characteristics of Black-capped and Carolina chickadees at the range interface in northern Indiana. Jack-Pine Warbler 56: 170179.

- 1981. Narrowly disjunct allopatry between Black-capped and Carolina chickadees in northern Indiana. Wilson Bull. 93: 54-66.

NEI, M. 1978. Estimation of average heterozygosity and genetic distance from a small number of individuals. Genetics 89: 583-590.

Nevo, E. 1978. Genetic variation in natural populations: patterns and theory. Theoret. Popul. Biol. 13: 121-177.

PaYne, R. B. 1981. Population structure and social behavior: models for testing the ecological significance of song dialects in birds. Pp. 108-120 in Natural selection and social behavior (R. D. Alexander and D. W. Tinkle, Eds.). New York, Chiron Press.

Phillips, A. R., J. Marshall, \& G. Monson. 1964. The birds of Arizona. Tucson, Univ. Arizona Press.
Prager, E. M., A. H. Brush, R. A. Nolan, M. NaKaNISHI, \& A. C. WILSON. 1974. Slow evolution of transferrin and albumin in birds according to microcomplement fixation analysis. J. Mol. Evol. 3: 263-278.

RISING, J. D. 1968. A multivariate assessment of interbreeding between the chickadees Parus atricapillus and P. carolinensis. Syst. Zool. 17: 160-169.

Robbins, M. B., M. J. Braun, \& E. TobeY. 1986. Morphological and vocal variation across a contact zone between the chickadees Parus atricapillus and P. carolinensis. Auk 103: 655-666.

ROGERS, J. S. 1972. Measures of genetic similarity and genetic distance. Stud. Genetics, Univ. Texas Publ. 7213: 145-153.

Sibley, C. G., \& J. E. Ahlquist. 1982. The relationships of the Yellow-breasted Chat (Icteria virens) and the alleged slowdown in the rate of macromolecular evolution in birds. Postilla 187: 1-19.

, \& F. C. Sibley. 1964. Hybridization in the Red-eyed Towhees of Mexico: the populations of the southeastern plateau region. Auk 81: 479504.

SWOFFORD, D. L., \& R. B. SElANDER. 1981. BIOSYS1: a FORTRAN program for the comprehensive analysis of electrophoretic data in population genetics and systematics. J. Heredity 72: 281-283.

TANNER, J. T. 1952. Black-capped and Carolina chickadees in the southern Appalachian Mountains. Auk 69: 407-442.

THÖNEN, W. 1962. Stimmgeographische, ökologische, und verbreitungsgeschichtliche Studien über die Mönchsmeise (Parus montanus Conrad). Ornithol. Beob. 59: 101-172.

WhitTAKER, R. H. 1956. Vegetation of the Great Smoky Mountains. Ecol. Monogr. 22: 1-44.

WRIGHT, S. 1978. Evolution and the genetics of populations. Vol. 4, Variability within and among natural populations. Chicago, Univ. Chicago Press.

YANG, S. Y., \& J. L. PATTON. 1981. Genic variability and differentiation in the Galapagos finches. Auk 98: $230-242$. 
APPENDIx. Allele frequencies and electrophoretic conditions for polymorphic protein loci..$^{\text {a,b }}$

\begin{tabular}{|c|c|c|c|c|c|c|c|}
\hline E.C. no. & $\begin{array}{l}\text { Locus } \\
\text { (acro- } \\
\text { nym) }\end{array}$ & $\begin{array}{l}\text { P. carolinen- } \\
\text { sis }\end{array}$ & $\begin{array}{l}\text { P. atricapil- } \\
\quad \text { lus }\end{array}$ & $\begin{array}{l}\text { Contact } \\
\text { zone }\end{array}$ & P. gambeli & $\begin{array}{l}\text { Tis- } \\
\text { sue }^{c}\end{array}$ & Buffer \\
\hline \multirow[t]{3}{*}{ 1.1.1.8 } & \multicolumn{5}{|c|}{$\begin{array}{l}\left.\text { Glycerol-3-phosphate dehydrogenase(NAD }{ }^{+}\right)-1 \\
\text { (GPD-1) }\end{array}$} & \multirow[t]{3}{*}{$\mathbf{M}$} & \multirow[t]{3}{*}{ Tris-borate, $\mathrm{pH} 8.1$} \\
\hline & a & - & - & 0.036 & - & & \\
\hline & $\mathbf{b}$ & 1.000 & 1.000 & 0.964 & 1.000 & & \\
\hline \multirow[t]{4}{*}{ 1.1.1.14 } & \multicolumn{5}{|c|}{ L-iditol dehydrogenase (IDH) } & \multirow[t]{4}{*}{$\mathrm{L}$} & \multirow[t]{4}{*}{ Tris-citrate, pH 7.5 (NAD) ${ }^{\mathrm{d}}$} \\
\hline & $(n)$ & 15 & 18 & 0 & 0 & & \\
\hline & a & 0.967 & 1.000 & - & - & & \\
\hline & $\mathbf{b}$ & 0.033 & - & - & - & & \\
\hline \multirow[t]{4}{*}{ 1.1.1.42 } & \multicolumn{5}{|c|}{ Isocitrate dehydrogenase(NADP $\left.{ }^{+}\right)-2$ (ICD-2) } & \multirow[t]{4}{*}{$\mathbf{M}$} & \multirow[t]{4}{*}{ Tris-borate, $\mathrm{pH} 8.1$ (NADP) } \\
\hline & $(n)$ & 19 & 20 & 14 & 15 & & \\
\hline & a & 0.947 & 1.000 & 1.000 & 1.000 & & \\
\hline & & 0.053 & - & - & - & & \\
\hline \multirow[t]{4}{*}{ 2.6.1.1 } & \multicolumn{5}{|c|}{ Aspartate aminotransferase-1 (AAT-1) } & \multirow[t]{4}{*}{$\mathbf{M}$} & \multirow[t]{4}{*}{ Phosphate-citrate, pH 6.0} \\
\hline & a & - & 0.025 & - & - & & \\
\hline & $\mathbf{b}$ & 1.000 & 0.975 & 0.964 & 1.000 & & \\
\hline & c & - & - & 0.036 & - & & \\
\hline \multirow[t]{3}{*}{ 2.6.1.1 } & \multicolumn{5}{|c|}{ Aspartate aminotransferase-2 (AAT-2) } & \multirow[t]{3}{*}{$\mathbf{M}$} & \multirow[t]{3}{*}{ Phosphate-citrate, $\mathrm{pH} 6.0$} \\
\hline & a & 0.025 & - & - & - & & \\
\hline & $\mathbf{b}$ & 0.975 & 1.000 & 1.000 & 1.000 & & \\
\hline \multirow[t]{4}{*}{ 2.6.1.2 } & Alanin & le aminotrans & ferase-2 (AL & AT-2) & & $\mathbf{M}$ & Phosphate-citrate, $\mathrm{rH} 6.0$ \\
\hline & $(n)$ & 16 & 13 & 14 & 15 & & \\
\hline & a & - & - & - & 1.000 & & \\
\hline & $\mathbf{b}$ & 1.000 & 1.000 & 1.000 & - & & \\
\hline 2.7.3.2 & Creatir & ne kinase-2 $(\mathrm{C}$ & K-2) & & & $\mathbf{M}$ & Tris-citrate, $\mathrm{pH} 7.5$ \\
\hline & $(n)$ & 20 & 20 & 13 & 15 & & \\
\hline & a & 1.000 & 0.975 & 1.000 & 1.000 & & \\
\hline & & - & 0.025 & - & - & & \\
\hline 2.7.5.1 & Phospl & hoglucomutas & e (PGM) & & & $\mathrm{H}$ & Tris-maleate, pH 7.5 \\
\hline & a & 0.025 & - & - & - & & \\
\hline & b & 0.975 & 0.975 & 1.000 & 1.000 & & \\
\hline & C & 一 & 0.025 & 一 & - & & \\
\hline 3.1.1.2 & Umbel & liferyl acetate & esterase-1 & EST-1) & & $\mathbf{M}$ & Tris-borate, $\mathrm{pH} 8.1$ \\
\hline & a & - & 0.025 & - & - & & \\
\hline & b & 0.950 & 0.975 & 1.000 & 1.000 & & \\
\hline & C & 0.050 & - & - & - & & \\
\hline 3.4.11.4 & $\begin{array}{c}\text { Tripep } \\
\text { a }\end{array}$ & $\begin{array}{l}\text { tide aminope } \\
\text { _ }\end{array}$ & ptidase-1 (T) & RI-1) & - & $\mathbf{M}$ & Tris-citrate, pH 7.5 \\
\hline & b & 1.000 & 1.000 & 0.964 & 1.000 & & \\
\hline 3.4.11.4 & Tripep & tide aminope & ptidase-2 (T) & RI-2) $)^{\mathbf{e}}$ & & $\mathbf{M}$ & Tris-citrate, $\mathrm{pH} 7.5$ \\
\hline & a & 0.025 & - & - & 0.033 & & \\
\hline & $\mathbf{b}$ & 0.975 & 1.000 & 1.000 & 0.967 & & \\
\hline 3.4.13.9 & Proline & e dipeptidase- & $-1(\mathrm{PRO}-1)^{\mathrm{e}}$ & & & $\mathbf{M}$ & Tris-citrate, pH 7.5 \\
\hline & a & - & 0.050 & - & 0.033 & & \\
\hline & $\mathbf{b}$ & 0.175 & 0.375 & 0.357 & 0.933 & & \\
\hline & c & 0.825 & 0.575 & 0.643 & 0.033 & & \\
\hline 3.4.13.9 & Proline & dipeptidase- & $-2(\mathrm{PRO}-2)^{\mathrm{e}}$ & & & $\mathbf{M}$ & Tris-citrate, pH 7.5 \\
\hline & a & - & 0.125 & 0.036 & 0.067 & & \\
\hline & $\mathbf{b}$ & 0.950 & 0.825 & 0.821 & 0.933 & & \\
\hline & c & 0.050 & 0.050 & 0.143 & - & & \\
\hline
\end{tabular}


APPENDIX. Continued

\begin{tabular}{|c|c|c|c|c|c|c|c|}
\hline E.C. no. & $\begin{array}{l}\text { Locus } \\
\text { (acro- } \\
\text { nym) }\end{array}$ & $\begin{array}{l}P . \text { carolinen } \\
\text { sis }\end{array}$ & $\begin{array}{c}\text { P. atricapil- } \\
\text { lus }\end{array}$ & $\begin{array}{l}\text { Contact } \\
\text { zone }\end{array}$ & P. gambeli & $\begin{array}{l}\text { Tis- } \\
\text { sue }^{c}\end{array}$ & Buffer \\
\hline \multirow[t]{7}{*}{ 3.4.13.11 } & \multicolumn{5}{|c|}{ Dipeptidase-1 (DIP-1) } & $\mathbf{M}$ & Tris-citrate, $\mathrm{pH} 7.5$ \\
\hline & a & 0.150 & 0.150 & 0.179 & - & & \\
\hline & b & - & - & - & 0.033 & & \\
\hline & c & 0.750 & 0.775 & 0.786 & - & & \\
\hline & d & 0.075 & 0.075 & 0.036 & 0.900 & & \\
\hline & e & 0.025 & - & - & - & & \\
\hline & f & - & - & - & 0.067 & & \\
\hline \multirow[t]{5}{*}{ 3.4.13.11 } & \multicolumn{5}{|c|}{ Dipeptidase-2 (DIP-2)e } & $\mathbf{M}$ & Tris-citrate, $\mathrm{pH} 7.5$ \\
\hline & a & - & - & - & 0.033 & & \\
\hline & $\mathbf{b}$ & 0.950 & 1.000 & 1.000 & 0.933 & & \\
\hline & c & 0.050 & - & - & - & & \\
\hline & d & - & - & - & 0.033 & & \\
\hline \multirow[t]{4}{*}{ 5.3.1.8 } & \multicolumn{5}{|c|}{ Mannosephosphate isomerase (MPI) } & $\mathbf{M}$ & Tris-borate, $\mathrm{pH} 8.1$ \\
\hline & a & - & 0.025 & 0.036 & - & & \\
\hline & b & 0.900 & 0.950 & 0.964 & 1.000 & & \\
\hline & c & 0.100 & 0.025 & - & - & & \\
\hline
\end{tabular}

a The following loci were monomorphic in all individuals assayed: (E.C. numbers and acronyms in parentheses): lactate dehydrogenase-1 \& 2 (1.1.1.27; LDH), malate dehydrogenase-1 \& 2 (1.1.1.37; MDH), isocitrate dehydrogenase(NADP $\left.{ }^{+}\right)-1$, (1.1.1.42; ICD), phosphogluconate dehydrogenase (1.1.1.43; PGD), glyceraldehyde-phosphate dehydrogenase (1.2.1.12; GAPDH), glutamate dehydrogenase (1.4.1.2; GLUD), superoxide dismutase-1 \& 2 (1.15.1.1; SOD), alanine aminotransferase-1 (2.6.1.2; ALAT), creatine kinase-1 (heart locus; 2.7.3.2; CK), adenylate kinase (2.7.4.3; $\mathrm{AK})$, acid phosphatase (3.1.3.2; $\mathrm{ACP}$ ), adenosine deaminase (3.5.4.4; ADA), glucosephosphate isomerase (5.3.1.9; GPI), myoglobin (Mb), hemoglobin- $\alpha$ \& $\beta$ (Hb).

b Unless otherwise noted, $n=20$ for carolinensis and atricapillus, $n=14$ for contact zone, and $n=15$ for gambeli.

${ }^{c} \mathrm{M}=$ muscle, $\mathrm{H}=$ heart, $\mathrm{L}=$ liver.

d Nicotine adenine dinucleotide $\left(\mathrm{NAD}^{+}\right)$or nicotine adenine dinucleotide phosphate $\left(\mathrm{NADP}^{+}\right)$added to gel buffer at 2-5 micromolar concentration.

e Peptidase substrates were leucylglycylglycine for tripeptide aminopeptidases, leucylalanine for dipeptidases, and phenylalanylproline for proline dipeptidases. 